\title{
China and East Asian trade: the decoupling fallacy, crisis and policy challenges
}

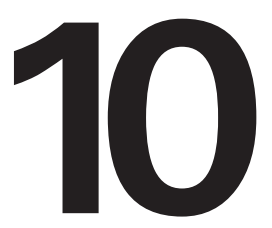

\section{Prema-chandra Athukorala and Archanun Kohpaiboon}

The 'decoupling' thesis - the notion that the East Asian region has become a self-contained economic entity with the potential for maintaining its own growth dynamism independent of the economic outlook for the traditional industrialised-market economies - was a popular theme in Asian policy circles in the first decade of the new millennium until the onset of the recent global financial crisis. ${ }^{1}$ The empirical basis for this was provided by studies of trade patterns based on readily available trade data, which revealed a continuous increase in trade among the countries in the region (intra-regional trade) since the late 1980s - a process that received added impetus from the subsequent emergence of China as a world export powerhouse. A few studies questioned the validity of this inference in a context in which international production fragmentation and the related network trade had been rapidly expanding with East Asia as its centre of gravity (Roach 2009:Ch. 1; Bergsten et al. 2006; Athukorala 2005; Garnaut 2003). The decoupling thesis continued to dominate the policy scene, however, presumably because it fitted well with the East Asian growth euphoria of the day.

The global financial crisis has served to reveal the fragility of the decoupling thesis since all major East Asian countries, including China, have experienced precipitous trade contractions. Consequently, the policy debate in East Asia has made a U-turn from the complacency of the decoupling thesis to a call for the rebalancing of East Asian growth with a view to reducing its susceptibility to the vicissitudes of the global business cycle (ADB 2010; IMF 2010).

\footnotetext{
1 See Urata (2006), Yoshitomi (2007) and Park and Shin (2009) and the works cited therein. All these authors are concerned with 'trade decoupling' as opposed to the ability of large Asian economies like India and China to continue to grow strongly on the basis of domestic demand expansion even if growth in the developed world slows down. This chapter focuses solely on the 'trade decoupling' debate.
} 
What went wrong with the decoupling thesis? Was the trade-integration story that underpinned the decoupling thesis simply a statistical artefact, resulting from a failure to incorporate the realities of an era of global production sharing? What are the policy challenges faced by the East Asian economies in the postglobal financial crisis era? Is there room for an integrated policy response that marks a clear departure from the pre-crisis policy stance favouring outwardoriented development strategies? This chapter aims to probe these and related issues through a comparative analysis of the export experiences of China and other East Asian economies in the aftermath of the crisis against the backdrop of a systematic analysis of pre-crisis trade patterns.

The decoupling thesis is based on the traditional notion of horizontal specialisation, according to which international trade is an exchange of goods that are produced from start to finish in just one country. It ignores the implications for trade-flow analysis of the continuing process of global production sharing ${ }^{2}$ the breaking up of the production processes into separated stages, with each country specialising in a particular stage of the production sequence - and the increasingly important role played by China and other East Asian countries in the resultant global production network. In a context in which production sharingbased trade is growing rapidly, trade-flow analysis based on the assumption of horizontal specialisation can lead to misleading inferences about the nature and extent of trade integration among countries for three reasons.

First, in the presence of global production sharing, trade data are doublecounted because goods-in-process cross multiple international borders before becoming embodied in the final product. Thus, the total amount of recorded trade could be a multiple of the value of final goods. Second, and perhaps more importantly, trade shares calculated using reported data can lead to wrong inferences as to the relative importance of the 'region' and the rest of the world for the growth dynamism of a given country, even controlling for doublecounting in trade. This is because 'fragmentation trade' and trade in related final goods ('final trade') are unlikely to follow the same patterns. Third, the intra-regional trade ratio estimated by lumping together imports and exports tends to hide a significant asymmetry in regional trade patterns of imports and exports in a context in which network-related trade is growing rapidly.

Given these concerns, a meaningful analysis of trade patterns requires systematic separation of parts and components (henceforth referred to as 'components') from final (assembled) products in reported trade data. We do this through a careful disaggregation of trade data based on Revision Three of the Standard International Trade Classification (SITC, Rev. 3) extracted from the United Nations trade-data reporting system (UN n.d.). ${ }^{3}$ 
For the purpose of this chapter, East Asia is defined to include Japan and developing East Asia, which covers the newly industrialised economies (NIEs) of North Asia (South Korea, Taiwan and Hong Kong), China and members of the Association of South-East Asian Nations (ASEAN). Among the ASEAN countries, Myanmar is not covered because of a lack of data and Brunei, Cambodia and Laos are treated as a residual group because of data gaps. The East Asian experience is examined in the wider global context, focusing specifically on the comparative experiences of the North American Free Trade Agreement (NAFTA) and the European Union.

This chapter is structured as follows. The first section examines trade patterns in East Asia in the global context, paying attention to the nature and extent of production sharing and network-based trade, East Asia's role in this new form of international exchange and its implications for regional versus global economic integration. In the next section, the latest available data are used to examine the impact of the global financial crisis on the export performance of East Asian economies. The next section deals with post-crisis policy challenges, focusing on the emerging debate regarding rebalancing (or reshaping) development strategies. The final section summarises the key findings and draws some general inferences.

\section{Pre-crisis trade patterns}

Rapid export growth has been the hallmark of East Asia's rise in the global economy. The combined share of East Asian countries in world non-oil exports recorded a threefold increase between 1969-70 and 2006-07-from 11 per cent to 33 per cent. ${ }^{4}$ The region accounted for more than 40 per cent of the total increment in world exports in this period. In the 1970s and 1980s, Japan dominated the region's trade, accounting for nearly 60 per cent of its exports and imports. The picture has changed dramatically in the past two decades, with the share of developing East Asian countries increasing rapidly in the face of a relative decline in Japan's position in world trade. By the middle of this decade, these countries accounted for more than 80 per cent of total regional trade. The rise of China has been the dominant factor behind this structural shift, ${ }^{5}$ but the other countries in the region (Taiwan, Korea, Malaysia, Singapore, the Philippines, Thailand and, more recently, Vietnam) have also increased their world market shares.

\footnotetext{
4 Trade magnitudes throughout the chapter are measured in current US dollars unless otherwise indicated. Inter-temporal comparison calculations are made for the two-year averages relating to the end points of the period under study, so as to reduce the impact of year-to-year fluctuations of trade flows. All data reported, unless otherwise stated, are compiled from the UN Comtrade database (UN n.d.).

5 For details on China's rise as a major trading nation and the implications of this for the other countries in the region, see Athukorala (2009a, 2009b).
} 
China: The Next Twenty Years of Reform and Development

Rapid export growth in East Asia has been underpinned by a pronounced shift in the region's export structure away from primary commodities and towards manufacturing. By 2006-07, manufacturing accounted for 92 per cent of total exports from Asia - up from 78 per cent four decades ago. Within manufacturing, machinery and transport equipment (SITC 7)-particularly information and communication technology (ICT) products and electrical goods-has played a pivotal role in this structural shift. The share of Asia in world machinery and transport equipment exports increased from 14.5 per cent in 1994-05 to 42.4 per cent in 2006-07, with developing East Asia accounting for more than four-fifths of the increment. By 2006-07, more than 58 per cent of total world ICT exports originated from Asia, with China alone accounting for 23 per cent (Table 10.1). In electrical goods, China's world market share increased from 3.1 per cent to 20.6 per cent between these two years. Export dynamism in these product lines has been driven by the continuing process of global production sharing and the increasingly deep integration of East Asian countries into global production networks.

Table 10.1 Composition of manufacturing exports, 2006-07 (per cent)

\begin{tabular}{|c|c|c|c|c|c|c|c|c|c|}
\hline $\begin{array}{l}\text { Commodity } \\
\text { group }\end{array}$ & EA & Japan & DEA & China & $T W+K$ & ASEAN & NAFTA & EU15 & World \\
\hline $\begin{array}{l}\text { Chemicals } \\
\text { (SITC 5) }\end{array}$ & 0.1 & 0.1 & 0.1 & 0.1 & 0.1 & 0.0 & 0.2 & 0.2 & 0.2 \\
\hline $\begin{array}{l}\text { Resource-based } \\
\text { products } \\
\text { (SITC 6 - SITC 68) }\end{array}$ & 1.2 & 1.8 & 0.9 & 1.0 & 1.0 & 0.7 & 2.1 & 2.8 & 2.0 \\
\hline $\begin{array}{l}\text { Machinery } \\
\text { and } \\
\text { transport } \\
\text { equipment } \\
\text { (SITC 7) }\end{array}$ & 89.7 & 87.5 & 90.3 & 91.6 & 84.0 & 94.7 & 86.0 & 87.9 & 88.1 \\
\hline $\begin{array}{l}\text { Power- } \\
\text { generating } \\
\text { machines } \\
\text { (SITC 71) }\end{array}$ & 1.8 & 3.8 & 1.1 & 1.1 & 1.1 & 1.2 & 9.0 & 6.6 & 4.9 \\
\hline $\begin{array}{l}\text { Specialised } \\
\text { industrial } \\
\text { machines } \\
\text { (SITC 72) }\end{array}$ & 2.1 & 3.5 & 1.7 & 1.8 & 1.1 & 2.3 & 2.6 & 3.5 & 2.7 \\
\hline $\begin{array}{l}\text { Metal-working } \\
\text { machines } \\
\text { (SITC 73) }\end{array}$ & 0.3 & 0.6 & 0.2 & 0.2 & 0.3 & 0.1 & 0.4 & 0.7 & 0.5 \\
\hline $\begin{array}{l}\text { General } \\
\text { industrial } \\
\text { machinery } \\
\text { (SITC 74) }\end{array}$ & 1.3 & 1.7 & 1.2 & 1.4 & 0.9 & 1.2 & 2.4 & 3.5 & 2.3 \\
\hline ICT products & 60.5 & 33.2 & 68.9 & 69.2 & 59.7 & 78.3 & 27.6 & 22.9 & 41.1 \\
\hline
\end{tabular}


China and East Asian trade: the decoupling fallacy, crisis and policy challenges

\begin{tabular}{|c|c|c|c|c|c|c|c|c|c|}
\hline $\begin{array}{l}\text { Office/ } \\
\text { automatic } \\
\text { data-processing } \\
\text { machines } \\
\text { (SITC 75) }\end{array}$ & 19.6 & 8.2 & 23.1 & 29.0 & 8.7 & 27.0 & 7.2 & 7.6 & 12.4 \\
\hline $\begin{array}{l}\text { Telecommu- } \\
\text { nication } \\
\text { and sound- } \\
\text { recording } \\
\text { equipment } \\
\text { (SITC 76) }\end{array}$ & 18.7 & 9.0 & 21.7 & 28.3 & 16.1 & 14.9 & 9.6 & 7.9 & 13.1 \\
\hline $\begin{array}{l}\text { Semiconductors } \\
\text { and } \\
\text { semiconductor } \\
\text { devices } \\
\text { (SITC772+776) }\end{array}$ & 22.2 & 16.0 & 24.2 & 11.8 & 34.9 & 36.4 & 10.8 & 7.5 & 15.7 \\
\hline $\begin{array}{l}\text { Electrical } \\
\text { goods } \\
\text { (SITC 77-772-776) }\end{array}$ & 9.7 & 8.1 & 10.2 & 14.2 & 6.1 & 6.4 & 8.2 & 8.5 & 9.3 \\
\hline $\begin{array}{l}\text { Road } \\
\text { vehicles } \\
\text { (SITC 78) }\end{array}$ & 12.7 & 35.0 & 5.9 & 3.2 & 12.6 & 4.4 & 26.5 & 36.4 & 23.0 \\
\hline $\begin{array}{l}\text { Other } \\
\text { transport } \\
\text { equipment } \\
\text { (SITC 79) }\end{array}$ & 1.3 & 1.6 & 1.2 & 0.7 & 2.3 & 0.9 & 9.3 & 5.7 & 4.4 \\
\hline $\begin{array}{l}\text { Miscellaneous } \\
\text { manufacturing } \\
\text { (SITC 8) }\end{array}$ & 9.1 & 10.6 & 8.7 & 7.3 & 14.9 & 4.6 & 11.8 & 9.1 & 9.8 \\
\hline $\begin{array}{l}\text { Professional } \\
\text { and scientific } \\
\text { equipment } \\
\text { (SITC 87) }\end{array}$ & 5.5 & 5.8 & 5.4 & 4.0 & 11.0 & 2.6 & 8.2 & 5.9 & 6.3 \\
\hline $\begin{array}{l}\text { Photographic } \\
\text { apparatus } \\
\text { (SITC 88) }\end{array}$ & 2.3 & 3.6 & 1.9 & 2.4 & 1.2 & 1.3 & 1.3 & 1.8 & 2.1 \\
\hline $\begin{array}{l}\text { Total } \\
\text { manufacturing } \\
\text { exports }\end{array}$ & 100 & 100 & 100 & 100 & 100 & 100 & 100 & 100 & 100 \\
\hline US\$billion & 1826 & 428 & 1398 & 656 & 359 & 348 & 739 & 1366 & 4517 \\
\hline
\end{tabular}

Notes: Standard International Trade Classification (SITC) codes are given in parentheses. EA = East Asia; DEA = developing East Asia; TW $+\mathrm{K}=$ Taiwan and Korea; ASEAN6 = six main ASEAN countries; EU15 $=15$ member countries of the European Union; NAFTA = countries in the North American Free Trade Agreement (United States, Canada and Mexico).

Source: Compiled from United Nations (UN) n.d., Comtrade database, United Nations, New York.

The best available indicator of the intensity of global production sharing is the share of parts and components in total manufacturing trade. ${ }^{6}$ Reflecting

6 Henceforth, for the sake of brevity, we use the term 'components' in place of 'parts and components'. 
the rapid growth of global production sharing, the share of components in manufacturing trade has sharply increased across all major countries in the region (Table 10.2). In 2006-07, components accounted for 34.1 per cent of East Asian manufacturing exports (42.1 per cent of manufacturing imports) compared with a world average of 27.1 per cent (27.3 per cent of imports). The share of components is particularly high among the ASEAN countries. There is a remarkable similarity in component share figures in exports and imports across countries, reflecting overlapping specialisation patterns in component assembly among countries in the region.

Table 10.2 Share of parts and components in manufacturing trade, 1992-03 and 2006-07 (per cent)

\begin{tabular}{lcccc}
\hline & \multicolumn{2}{c}{ Exports } & \multicolumn{2}{c}{ Imports } \\
Region & $\mathbf{1 9 9 2 - 9 3}$ & $\mathbf{2 0 0 6 - 0 7}$ & $\mathbf{1 9 9 2 - 9 3}$ & $\mathbf{2 0 0 6 - 0 7}$ \\
\hline East Asia & 20.2 & 34.1 & 27.2 & 42.1 \\
Japan & 23.9 & 34.4 & 19.3 & 29.9 \\
Developing East Asia & 17.3 & 34 & 29 & 44.2 \\
China (PRC) & 7.4 & 25.6 & 20.4 & 44 \\
Hong Kong, China & 15.8 & 33.3 & 24.1 & 48.5 \\
Taiwan & 24.7 & 44.2 & 29.5 & 38.9 \\
Republic of Korea & 18.1 & 47.3 & 30.1 & 31.9 \\
ASEAN & 22.7 & 44.2 & 36 & 47.9 \\
Indonesia & 3.8 & 21.5 & 27 & 21.8 \\
Malaysia & 27.7 & 53.6 & 40.5 & 50 \\
The Philippines & 32.9 & 71.7 & 32.6 & 61.3 \\
Singapore & 29 & 49.3 & 39.9 & 60.4 \\
Thailand & 14.1 & 29.9 & 30.6 & 36.1 \\
Vietnam & $\mathrm{n} . \mathrm{a}$. & 11.0 & $\mathrm{n} . \mathrm{a}$. & 19.1 \\
South Asia & 2.3 & 8.2 & 16.6 & 23.8 \\
India & 3 & 10.4 & 17.5 & 22.9 \\
NAFTA & 28.4 & 31.2 & 37.4 & 28.8 \\
Mexico & 42.1 & 34.6 & 29.4 & 36.1 \\
EU15 & 18.3 & 22.4 & 21.2 & 23.2 \\
Industrialised countries & 20.4 & 25.2 & 22.6 & 23.4 \\
Developing countries & 14.6 & 29.2 & 11.9 & 33.6 \\
World & 19.3 & 27.1 & 19.6 & 27.3 \\
\hline
\end{tabular}

n.a. not available

Source: Compiled from United Nations (UN), n.d., Comtrade database, United Nations, New York.

The rapid increase in component intensity (percentage shares of parts and components) in East Asian trade is closely associated with cross-border component trade within regional production networks. As can be seen in Table 10.3, components account for a much larger share of intra-regional trade in East 
Asia than these countries' shares of world trade and trade with the European Union and NAFTA. Moreover, the share of components in total intra-regional imports is much larger than in exports - and has increased at a faster rate. This reflects the fact that the region relies on the rest of the world more as a market for final goods than as a market for components. Within East Asia, ASEAN countries stand out for the high share of components in their intra-regional trade flows (more than 60 per cent in 2006-07). According to country-level data, the share of components in manufacturing exports and imports amounted to more than four-fifths in Singapore, Malaysia and the Philippines and more than two-thirds in Thailand. South Korea and Taiwan are also involved in sizeable trade in components with other countries in the region. In 2006-07, components accounted for 59.2 per cent and 74 per cent of China's imports from developing Asia and ASEAN countries, respectively, compared with 44 per cent in total imports.

Table 10.3 Share of parts and components in bilateral trade flows, 2006-07 (per cent)

\begin{tabular}{|c|c|c|c|c|c|c|c|c|}
\hline $\begin{array}{l}\text { Reporting } \\
\text { country }\end{array}$ & EA & Japan & DEA & PRC & ASEAN & NAFTA & EU15 & World \\
\hline \multicolumn{9}{|l|}{ (a) Exports } \\
\hline East Asia & 47.6 & 32.9 & 50.1 & 51.6 & 54.5 & 25.1 & 24.1 & 34.1 \\
\hline Japan & 42.0 & 0.0 & 42.0 & 41.5 & 47.9 & 31.5 & 30.4 & 34.4 \\
\hline $\begin{array}{l}\text { Developing } \\
\text { East Asia }\end{array}$ & 48.1 & 33.4 & 53.9 & 0.0 & 65.2 & 22.7 & 21.6 & 34.0 \\
\hline China (PRC) & 36.2 & 25.2 & 40.6 & 0.0 & 49.1 & 17.1 & 16.3 & 25.6 \\
\hline Korea & 61.9 & 51.5 & 63.5 & 57.3 & 63.7 & 36.6 & 26.8 & 44.2 \\
\hline Taiwan & 51.5 & 59.0 & 50.5 & 39.5 & 61.2 & 35.0 & 37.6 & 44.2 \\
\hline ASEAN10 & 58.2 & 39.9 & 61.4 & 64.0 & 56.0 & 32.1 & 33.9 & 44.2 \\
\hline NAFTA & 46.7 & 36.5 & 49.8 & 34.8 & 67.9 & 28.8 & 30.6 & 31.2 \\
\hline EU15 & 31.4 & 18.7 & 34.8 & 30.4 & 46.5 & 22.1 & 22.0 & 22.4 \\
\hline \multicolumn{9}{|l|}{ (b) Imports } \\
\hline East Asia & 51.7 & 48.8 & 52.8 & 34.8 & 68.3 & 54.7 & 33.1 & 42.1 \\
\hline Japan & 34.2 & 0.0 & 34.2 & 23.1 & 44.9 & 41.0 & 18.9 & 29.9 \\
\hline $\begin{array}{l}\text { Developing } \\
\text { East Asia }\end{array}$ & 55.5 & 47.7 & 59.5 & 0.0 & 74.3 & 40.3 & 31.7 & 44.2 \\
\hline China (PRC) & 55.2 & 47.5 & 59.2 & 0.0 & 74.0 & 40.1 & 31.6 & 44.0 \\
\hline Korea & 33.0 & 26.6 & 38.1 & 26.1 & 55.7 & 38.9 & 22.9 & 31.9 \\
\hline Taiwan & 46.7 & 33.8 & 58.3 & 44.1 & 68.8 & 40.2 & 28.0 & 38.9 \\
\hline ASEAN10 & 50.3 & 47.2 & 51.4 & 40.1 & 55.9 & 67.5 & 41.7 & 47.9 \\
\hline NAFTA & 29.4 & 39.3 & 26.0 & 17.7 & 40.5 & 36.3 & 25.1 & 28.8 \\
\hline EU15 & 25.0 & 33.6 & 22.8 & 14.9 & 37.9 & 34.1 & 22.1 & 23.4 \\
\hline
\end{tabular}

Notes: EA = East Asia; DEA = developing East Asia; ASEAN6 = six main ASEAN countries; EU15 = 15 member countries of the European Union; NAFTA = countries in the North American Free Trade Agreement (United States, Canada and Mexico). 


\section{China in East Asian trade}

Manufacturing products dominate China-East Asia trade flows, accounting for nearly 90 per cent of imports and exports (Table 10.4). In China's total manufacturing imports from East Asia, the share of components increased from 18 per cent in 1994-05 to more than 44 per cent in 2006-07. Within manufacturing, the share of components is much larger in machinery and transport equipment imports, at nearly three-quarters in 2006-07. The shares of components in manufacturing exports also have increased over the years, but the magnitudes are significantly lower compared with those in total imports. Interestingly, although China's importance as a market for the rest of East Asia has increased during the period under study (see below), the importance of the region for China's export expansion has declined notably, as it absorbed only 33.7 per cent of China's total merchandise exports in 2006-07-down from 55.8 per cent in 1993. East Asia's share in China's total imports increased marginally from 21.3 per cent in 1992-03 to 28.8 per cent in 2006-07.

Table 10.4 China's trade with the rest of East Asia (per cent)

\begin{tabular}{|c|c|c|c|c|}
\hline \multirow[b]{2}{*}{ A: Commodity composition } & \multicolumn{2}{|c|}{ Exports } & \multicolumn{2}{|c|}{ Imports } \\
\hline & 1994-95 & $2006-07$ & 1994-95 & 2006-07 \\
\hline A1: Total trade & 100 & 100 & 100 & 100 \\
\hline Primary products & 16.2 & 10.4 & 23.5 & 13.5 \\
\hline Manufacturing & 83.4 & 89.2 & 76.1 & 86.3 \\
\hline Machinery and transport equipment (SITC 7) & 20.8 & 46.6 & 26.4 & 49.7 \\
\hline Electronics and electrical goods $(75+76+77)$ & 16.7 & 40.6 & 15.0 & 43.0 \\
\hline Miscellaneous manufacturing (SITC 8) & 43.3 & 25.5 & 7.7 & 12.5 \\
\hline Apparel (84) & 18.5 & 10.3 & 1.3 & 0.4 \\
\hline A2: Parts and components & 100 & 100 & 100 & 100 \\
\hline Machinery and transport equipment (SITC 7) & 90.2 & 95.5 & 92.1 & 95.1 \\
\hline Electronic and electrical goods $(75+76+77)$ & 81.0 & 87.7 & 74.6 & 85.7 \\
\hline Transport equipment (78) & 3.7 & 2.3 & 0.7 & 1.8 \\
\hline Other & 9.8 & 4.5 & 3.8 & 3.3 \\
\hline \multicolumn{5}{|c|}{ B: Parts and component share in manufacturing trade } \\
\hline Total manufacturing & 7.5 & 25.6 & 17.9 & 44.4 \\
\hline Machinery and transport equipment (SITC 7) & 6.8 & 24.4 & 46.1 & 73.3 \\
\hline Electronic and electrical goods $(75+76+77)$ & 30.3 & 49.3 & 73.1 & 82.5 \\
\hline Transport equipment & 25.4 & 50.1 & 16.3 & 79.0 \\
\hline Other & 1.4 & 4.0 & 18.0 & 14.4 \\
\hline
\end{tabular}




\begin{tabular}{lcccc}
\hline C: Trade with East Asia in China's world trade & & & & \\
C1: Total trade & 55.8 & 33.7 & 21.3 & 28.4 \\
Primary products & 74.6 & 59.2 & 27.9 & 15.5 \\
Manufacturing & 53.3 & 32.2 & 19.9 & 32.7 \\
Machinery and transport equipment (SITC 7) & 53.7 & 33.1 & 13.4 & 32.0 \\
Electronic and electrical goods (75 + 76 + 77) & 60.4 & 34.6 & 53.0 & 52.0 \\
Miscellaneous manufacturing (SITC 8) & 50.1 & 29.1 & 27.2 & 36.0 \\
Apparel (84) & 59.1 & 38.1 & 45.1 & 52.9 \\
C2: Parts and components & 60.1 & 44.7 & 22.4 & 38.7 \\
Machinery and transport equipment (SITC 7) & 59.8 & 44.6 & 21.7 & 38.6 \\
Electronic and electrical goods (75 + 76 + 77) & 61.2 & 46.0 & 68.9 & 56.2 \\
Transport equipment & 44.2 & 23.2 & 5.6 & 21.7 \\
Miscellaneous manufacturing (SITC 8) & 62.2 & 45.7 & 30.3 & 40.7 \\
\hline
\end{tabular}

Note: East Asia = developing East Asia and Japan.

Source: Compiled from United Nations (UN) n.d., Comtrade database, United Nations, New York.

Table 10.5 summarises data on China-East Asia trade relations at the individual country level. Data on the geographic profile of China's manufacturing imports from the region are in Panel A. Panel B gives data on the relative importance of China as an export destination of the East Asian economies. Nearly 60 per cent of China's manufacturing imports originate in East Asia. The bulk of these imports come from Japan, Korea and Taiwan. The share of imports coming from the other East Asian countries is small, although growing fast. In 2007, China accounted for only 21.2 per cent of total manufacturing exports from the rest of East Asia. At the individual country level, China accounted for 33 per cent and 27 per cent of exports from Taiwan and Korea, respectively. China was also one of the most important export destinations of the Philippines, accounting for more than one-fifth of total exports. For all other ASEAN countries, the figures are much smaller - varying from 8 per cent to 13.5 per cent. Clearly, aggregate data hide some significant differences among East Asian countries in trade links with China, with China's intra-regional trade concentrated largely in trade with Japan, Korea and Taiwan. 
China: The Next Twenty Years of Reform and Development

Table 10.5 East Asia-China manufacturing trade

\begin{tabular}{lcccc}
\hline Region & \multicolumn{2}{c}{$\begin{array}{c}\text { A: Geographic profile } \\
\text { of China's imports }\end{array}$} & \multicolumn{2}{c}{$\begin{array}{c}\text { B: Exports to China relative } \\
\text { to total exports by country/ } \\
\text { region }\end{array}$} \\
& $\mathbf{1 9 9 4 - 9 5}$ & $\mathbf{2 0 0 6 - 0 7}$ & $\mathbf{1 9 9 4 - 9 5}$ & $\mathbf{2 0 0 6 - 0 7}$ \\
\hline East Asia & 58.2 & 58.6 & 7.6 & 21.2 \\
Japan & 20.9 & 16.4 & 5.5 & 17.3 \\
Developing East Asia & 37.1 & 42.2 & 8.2 & 21.6 \\
Hong Kong & 17.3 & 2.0 & 29.6 & 19.5 \\
Korea & 4.3 & 13.4 & 5.8 & 27.2 \\
Taiwan & 10.7 & 14.0 & 10.3 & 32.6 \\
ASEAN & 3.7 & 13.8 & 2.5 & 13.7 \\
Indonesia & 1.0 & 1.1 & 3.3 & 8.4 \\
Malaysia & 1.1 & 3.4 & 3.2 & 13.5 \\
The Philippines & 0.2 & 2.1 & 1.5 & 21.3 \\
Singapore & 0.8 & 2.3 & 1.8 & 12.2 \\
Thailand & 0.7 & 2.3 & 1.8 & 11.2 \\
Vietnam & 0.1 & 0.1 & 2.5 & 4.1 \\
Other countries & 41.8 & 41.4 & 1.5 & 3.7 \\
World & 100 & 100 & 2.7 & 6.7 \\
\hline
\end{tabular}

Sources: Compiled from United Nations (UN) n.d., Comtrade database, United Nations, New York; and Council for Economic Planning and Development n.d., Trade Data, CD-ROM, Council for Economic Planning and Development, Taipei (for data on Taiwan).

\section{Intra-regional trade patterns}

The previous section reveals three important features of the emerging trade patterns in East Asia compared with overall patterns of global trade. First, component trade has played a more important role in trade expansion in East Asia. Second, trade in components accounts for a much larger share in intraregional trade than is the case for the rest of the world. Third, China's rapid trade expansion largely reflects its role as an assembly centre within global production networks; China's trade links with the rest of East Asia are dominated by components for assembling final products, which are destined predominantly for markets in the rest of the world. Given these three peculiarities, conventional trade-flow analysis is bound to yield a misleading picture of the relative importance of intra-regional trade-compared with global trade - for growth in East Asia.

To illustrate this point, intra-regional trade shares are estimated separately for total manufacturing, components and final goods (total manufacturing net of components) (Table 10.6). The table covers trade in East Asia and three 
sub-regions therein, which relate to contemporary Asian policy debates on regional integration. Data for NAFTA and the European Union are reported for comparative purposes. Estimates are given for total trade (imports plus exports) as well as for exports and imports separately in order to illustrate possible asymmetries in trade patterns resulting from East Asia's increased engagement in fragmentation-based international exchange. ${ }^{7}$

Table 10.6 Intra-regional shares of manufacturing trade: total, parts and components and final trade, 1992-93 and 2006-07 (per cent)

\begin{tabular}{|c|c|c|c|c|c|c|}
\hline & East Asia & $\begin{array}{l}\text { Developing } \\
\text { East Asia }\end{array}$ & ASEAN $+3^{1}$ & ASEAN & NAFTA & EU15 \\
\hline \multicolumn{7}{|c|}{ Total trade } \\
\hline \multicolumn{7}{|l|}{ Exports } \\
\hline $1986-97$ & 28.4 & 25.1 & 17.3 & 17.4 & 49.1 & 65.5 \\
\hline $1992-93$ & 47.2 & 38.2 & 15.3 & 20.7 & 44.4 & 61.2 \\
\hline 2006-07 & 43.9 & 33.4 & 21.9 & 18.4 & 48.1 & 56.9 \\
\hline \multicolumn{7}{|l|}{ Imports } \\
\hline $1986-97$ & 48.6 & 22.9 & 34.4 & 11.0 & 29.9 & 69.7 \\
\hline $1992-93$ & 58.2 & 34.9 & 43.0 & 15.5 & 36.3 & 64.1 \\
\hline 2006-07 & 64.4 & 46.7 & 49.3 & 20.8 & 32.0 & 57.9 \\
\hline \multicolumn{7}{|c|}{ Trade (exports + imports) } \\
\hline $1986-97$ & 35.8 & 24.0 & 22.9 & 13.5 & 37.1 & 67.5 \\
\hline 1992-93 & 53.2 & 36.5 & 27.0 & 17.8 & 39.9 & 62.6 \\
\hline $2006-07$ & 55.1 & 40.0 & 30.4 & 20.1 & 38.4 & 57.4 \\
\hline \multicolumn{7}{|c|}{ Parts and components } \\
\hline \multicolumn{7}{|l|}{ Exports } \\
\hline 1992-93 & 50.2 & 42.6 & 33.7 & 30.3 & 43.5 & 62.3 \\
\hline 2006-07 & 61.1 & 53.9 & 35.3 & 25.4 & 46.9 & 55.9 \\
\hline \multicolumn{7}{|l|}{ Imports } \\
\hline $1992-93$ & 65.9 & 35.3 & 39.6 & 20.2 & 39.5 & 58.0 \\
\hline $2006-07$ & 66.9 & 50.9 & 47.8 & 22.9 & 39.9 & 55.2 \\
\hline \multicolumn{7}{|l|}{ Trade } \\
\hline $1992-93$ & 57.0 & 38.7 & 35.4 & 24.2 & 41.4 & 60.1 \\
\hline $2006-07$ & 62.9 & 52.1 & 40.2 & 23.1 & 43.2 & 55.5 \\
\hline \multicolumn{7}{|c|}{ Final goods ${ }^{2}$} \\
\hline \multicolumn{7}{|l|}{ Exports } \\
\hline $1992-93$ & 46.0 & 36.8 & 11.4 & 16.1 & 44.7 & 60.9 \\
\hline 2006-07 & 36.9 & 28.3 & 17.0 & 15.9 & 48.7 & 57.0 \\
\hline
\end{tabular}




\begin{tabular}{|c|c|c|c|c|c|c|}
\hline \multicolumn{7}{|l|}{ Imports } \\
\hline $1992-93$ & 55.4 & 34.7 & 43.4 & 12.9 & 35.3 & 65.6 \\
\hline $2006-07$ & 63.0 & 42.8 & 50.2 & 20.6 & 30.2 & 58.5 \\
\hline \multicolumn{7}{|l|}{ Trade } \\
\hline $1992-93$ & 50.3 & 35.7 & 25.4 & 14.3 & 39.4 & 63.2 \\
\hline $2006-07$ & 46.4 & 34.0 & 29.1 & 18.0 & 37.3 & 57.7 \\
\hline \multicolumn{7}{|c|}{ 1 ASEAN + Japan + Korea + China } \\
\hline \multicolumn{7}{|c|}{2 Total trade - parts and components. } \\
\hline \multicolumn{7}{|c|}{$\begin{array}{l}\text { Note: Intra-regional trade shares have been calculated excluding bilateral flows between China and Hon } \\
\text { Kong. }\end{array}$} \\
\hline
\end{tabular}

Trade patterns depicted by the unadjusted (standard) trade data affirm the perception underlying the decoupling thesis that Asia, and in particular East Asia, has become increasingly integrated through merchandise trade. In 200607, intra-regional trade accounted for 55.1 per cent of total manufacturing trade - up from 35.8 per cent in 1986-87. The level of intra-regional trade in East Asia was higher than that in NAFTA throughout this period and was rapidly approaching the level of the European Union 15. For developing East Asia (Asia excluding Japan) and ASEAN+3, the ratios are lower than the aggregate regional figure, but they have increased at a much faster rate. The intra-regional trade share of ASEAN has been much lower than the other two sub-regions.

The picture changes significantly, however, when components are netted out: the intra-East Asian share in final trade in 2006-07 was 46.4- down from 50.3 per cent in 1992-93. The estimates based on unadjusted data and data on final trade are vastly different for East Asia, particularly for developing East Asia and ASEAN. The level of trade in the two given years and the change over time in intra-regional trade shares are significantly lower for estimates based on final trade. Interestingly, we do not observe such a difference in estimates for NAFTA and the European Union.

The intra-regional shares calculated separately for imports and exports clearly illustrate the risk of making inferences about regional trade integration based on total (imports plus exports) data. There is a notable asymmetry in the degree of regional trade integration in East Asia. Unlike in the European Union and NAFTA, in East Asia, the increase over time in the intra-regional trade ratio (both measured using unadjusted data and data for final trade) has emanated largely from the rapid increase in intra-regional imports; the expansion in intra-regional exports has been consistently slower. The dependence of East Asia (and country sub-groups therein) on extra-regional markets (in particular, those in NAFTA 
and the European Union) for export-led growth is far greater than is revealed by the standard intra-regional trade ratios commonly used in the debate on regional economic integration. For instance, in 2007, only 43.9 per cent of total East Asian manufacturing exports was absorbed within the region, compared with an intra-regional share of 64.4 per cent in total manufacturing imports. For developing East Asia, the comparable figures were 33.4 per cent and 46.7 per cent, respectively. This asymmetry is clearly seen across all sub-regions within East Asia. The asymmetry between intra-regional shares of import and exports is much sharper when components are netted out. This is understandable given the heavy 'component bias' in Asian intra-regional trade and the multiple border crossing of parts and components within regional production networks. On the export side, the intra-regional share of final goods declined continuously from 46 per cent in 1995 to 37 per cent in 2007, whereas the intra-regional import share increased from 56 per cent to 63 per cent between these two time points.

In sum, these data support the hypothesis that, in a context in which global production sharing is expanding rapidly, standard trade flow analysis can generate misleading inferences regarding the process of economic integration through trade. When data on component trade are excluded from trade flows, these estimates suggest that extra-regional trade is much more important than intra-regional trade for continued growth in East Asia, whether or not Japan is included. Thus, the rising importance of global production sharing seems to have strengthened, rather than weakened, East Asia's link with the wider external economy. As we will see in the next section, this inference is basically consistent with the behaviour of trade flows in East Asia after the onset of the global financial crisis.

\section{Trade performance in the aftermath of the crisis}

A striking feature of the global economy since the onset of the global financial crisis in late 2007 has been the precipitous drop in global trade - at a rate faster than that during the Great Depression (Almunia et al. 2010; Krugman 2009). From April 2008 to June 2009, world trade contracted by about 20 per cent, which amounted to almost the total contraction in world trade during the first 30 months of the Great Depression (starting in April 1929). ${ }^{8}$ Interestingly, the trade contraction experienced by the East Asian countries during this period has been even greater than the contraction in total world trade (Figure 10.1 and Table 10.7).

8 Numbers derived from Almunia et al. (2010:Figure 5). 
China: The Next Twenty Years of Reform and Development

Figure 10.1 Growth of merchandise trade: East Asia, developing East Asia, China and ASEAN, January 2008 - November 2009 (year-on-year, per cent)

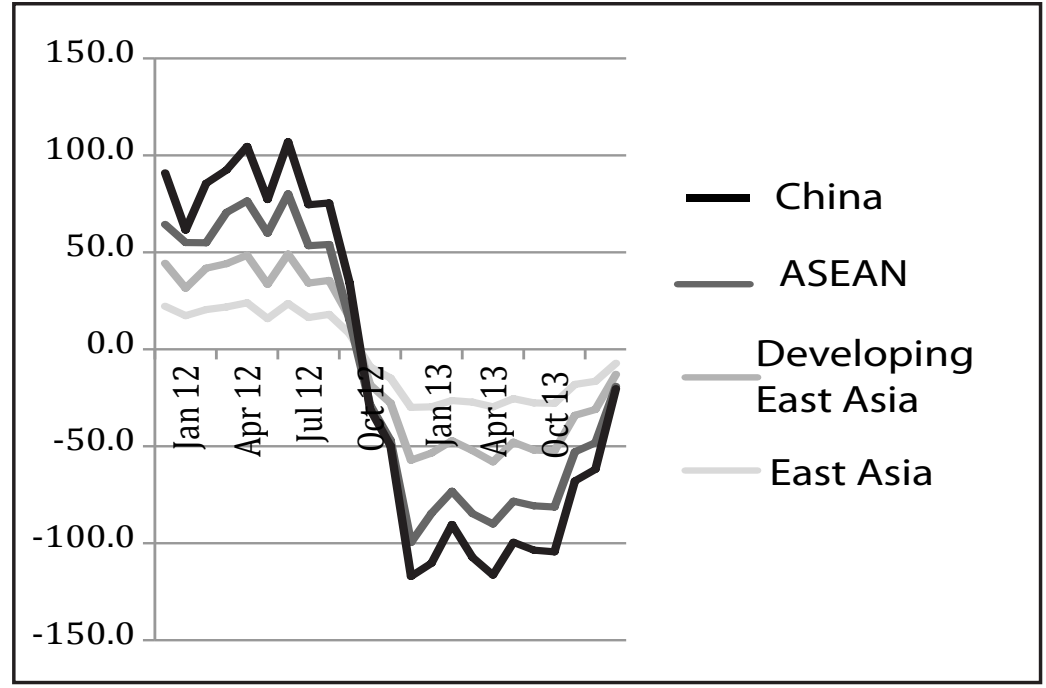

a) Exports

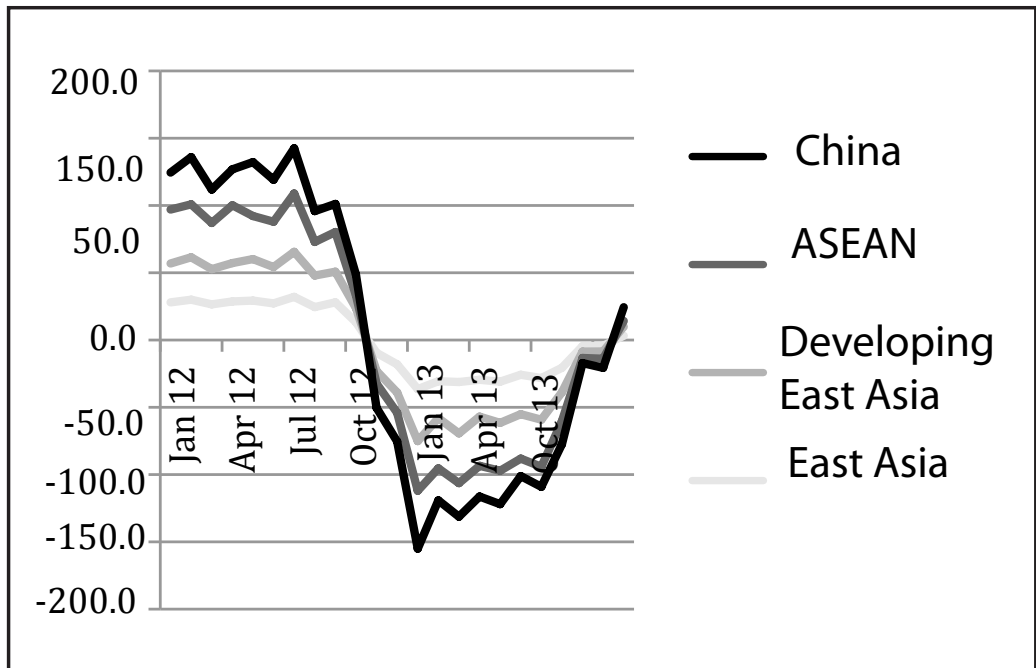

b) Imports

Source: Based on data compiled from CEIM database. 
Table 10.7 East Asia: growth of total merchandise exports and imports, 200701 - 200903 (year-on-year percentage change)

\begin{tabular}{|c|c|c|c|c|c|c|c|}
\hline & 200801 & 200802 & 200803 & 200804 & 200901 & 200902 & 200903 \\
\hline \multicolumn{8}{|l|}{ Exports } \\
\hline East Asia & 20.6 & 21.0 & 19.3 & -5.6 & -30.1 & -32.5 & -30.2 \\
\hline Japan & 22.9 & 16.4 & 15.2 & -8.1 & -42.1 & -41.1 & -38.2 \\
\hline $\begin{array}{l}\text { Developing } \\
\text { East Asia }\end{array}$ & 19.0 & 21.3 & 19.9 & -4.7 & -26.6 & -27.2 & -24.2 \\
\hline Hong Kong & 10.5 & 8.3 & 5.7 & -2.1 & -21.0 & -23.4 & -20.1 \\
\hline China & 21.1 & 22.4 & 23.0 & 4.6 & -20.1 & -22.7 & -20.3 \\
\hline Korea & 17.4 & 23.2 & 27.1 & -9.9 & -24.5 & -20.1 & -20.3 \\
\hline Taiwan & 17.4 & 18.2 & 7.6 & -24.6 & -35.9 & -28.3 & -18.5 \\
\hline ASEAN & 18.9 & 26.9 & 22.9 & -10.3 & -36.8 & -39.3 & 34.2 \\
\hline Indonesia & 31.9 & 29.4 & 27.9 & -5.3 & -32.5 & -33.2 & 31.1 \\
\hline Malaysia & 19.4 & 28.5 & 21.6 & -12.6 & -27.6 & -28.2 & 3.8 \\
\hline Philippines & -2.0 & -0.6 & 2.0 & -22.3 & -33.9 & -36.3 & -37.2 \\
\hline Singapore & 21.7 & 26.4 & 21.2 & -12.9 & -30.7 & -31.2 & -33.2 \\
\hline Thailand & 25.5 & 25.5 & 27.2 & -10.2 & -23.0 & -24.4 & -26.3 \\
\hline Vietnam & 27.7 & 31.8 & 37.5 & 6.0 & -14.8 & -11.7 & -7.3 \\
\hline \multicolumn{8}{|l|}{ Imports } \\
\hline East Asia & 29.6 & 29 & 29.8 & -4.1 & -32.5 & -33.1 & 30.7 \\
\hline Japan & 25.6 & 26.8 & 35.8 & 8.3 & -29.0 & -28.5 & -28.1 \\
\hline $\begin{array}{l}\text { Developing } \\
\text { East Asia }\end{array}$ & 29 & 28.9 & 26.6 & -8.0 & -32.1 & -34.2 & -33.2 \\
\hline Hong Kong & 12.0 & 9.6 & 7.0 & -4.0 & -20.8 & -22.3 & -25.2 \\
\hline China & 29.4 & 32.9 & 25.9 & -8.0 & -30.8 & -31.7 & -30.3 \\
\hline Korea & 29.0 & 30.5 & 42.9 & -8.8 & -32.8 & -35.6 & -11.9 \\
\hline Taiwan & 26.1 & 19.2 & 20.3 & -21.9 & -45.9 & -46.3 & -47.2 \\
\hline ASEAN & 37.9 & 36.2 & 32.6 & -5.0 & -37.2 & -36.7 & -35.3 \\
\hline Indonesia & 91.6 & 96.1 & 82.3 & 33.3 & -35.9 & -36.2 & -34.2 \\
\hline Malaysia & 16.1 & 17.3 & 14.5 & -17.1 & -36.8 & -36.1 & 4.8 \\
\hline Philippines & 22.1 & 8.4 & 4.5 & -23.4 & -30.3 & -31.3 & -32.1 \\
\hline Singapore & 32.1 & 35.4 & 32.9 & -9.3 & -30.0 & -28.1 & -29.2 \\
\hline Thailand & 39.6 & 25.7 & 37.8 & 3.8 & -39.7 & -40.5 & -37.3 \\
\hline Vietnam & 69.0 & 61.0 & 22.8 & -8.2 & -36.5 & -34.1 & -31.1 \\
\hline
\end{tabular}

Note: Growth rates calculated using current US dollar values.

Source: Compiled from CEIC Data Company.

Krugman (2009) points to the increased vertical integration of global production (the rise of global production sharing) as a possible explanation for the surprisingly large trade contraction in the present crisis compared with that in the 
Great Depression. Vertical integration of production implies that a given degree of contraction in demand for a final (assembled) product has ramifications for trade flows between the many countries involved in the production chain. Also, demand for components is susceptible to rapid stock adjustment by producers compared with final goods. Given that global production sharing is much more important for trade expansion in East Asia, this explanation also seems relevant for East Asia's greater trade contraction compared with overall trade contraction at the global level. A number of other factors are, however, also relevant for explaining the larger contraction in trade volume in the current crisis. These include the much larger contraction of trade credit, a greater share of consumer durables in contemporary global trade compared with the 1930s and the effect of recent advances in communication technology on inventory cycles and justin-time procurement practices. The current state of datum availability does not permit us to systematically delineate the impact of production sharing on trade contraction while appropriately controlling for these other possible factors. Instead, this section puts together some readily available data that have some bearing on this issue in order to set the stage for further analysis.

All major East Asian countries - including China, which was expected by the decoupling enthusiasts to cushion the rest of East Asia against a global economic collapse- experienced a precipitous trade contraction from about the last quarter of 2008 (Table 10.7). The remarkably synchronised nature of the trade contraction across countries in the region - in imports and exports - is generally consistent with the close trade ties in East Asia forged within regional production networks and the unique role of the region within global production networks.

Among the East Asian countries, Japan has been by far the worst hit. A large share of Japan's exports consists of capital goods and high-end durable consumer goods, such as cars and electrical machinery, machine tools and their components. Exports of capital goods and high-end consumer durables are concentrated heavily in the United States and other industrialised-country markets and are therefore directly exposed to the global economic decline. On the other hand, contrary to the predictions of the decoupling enthusiasts, Japan's growing exports to China have been indirectly affected by declining final (assembled) exports from China (Fukao and Yuan 2009). The degree of export contraction suffered by Taiwan and Korea has been smaller than that in Japan, but, on average, notably higher than in the other East Asian countries. As in the case of Japan, growing exports to China do not seem to have provided a cushion against collapse in world demand for these two countries. The relatively lower degree of export contractions experienced by Korea, Taiwan and the second-tier 
exporting countries in the region compared with Japan could possibly reflect consumer preferences for price-competitive low-end products in the crisis context.

An inspection of growth rates of exports of individual East Asian countries by destination provides no support for the view that East Asian economies have become less susceptible to the worldwide trade contraction because of regional growth dynamism. ${ }^{9}$ Intra-East Asian trade flows have in general contracted at a faster rate than these countries' exports to the United States and the European Union.

Exports to China from most countries in the region have contracted at a much faster rate than their imports from China-perhaps an indication of de-stocking of components by Chinese firms given the gloomy outlook for exports (Table 10.8). China's imports from Japan, Korea and Taiwan have shrunk more rapidly (at an average rate of 23.5 per cent) than imports from other countries. This is not surprising, given the dominant role played by these countries in the supply of components to ICT assembly activities in China, which are heavily exposed to contractions in import demand in the United States and other industrialised countries. Overall, China's intra-regional imports have contracted at a much faster rate than imports from the United States and the European Union.

Table 10.8 China: growth of total merchandise exports \& imports by trading partner countries, 200701 - 200904 (year-on-year percentage change, current US\$)

\begin{tabular}{lcccccccc}
\hline & $\mathbf{2 0 0 8}$ & $\mathbf{2 0 0 8}$ & $\mathbf{2 0 0 8}$ & $\mathbf{2 0 0 8}$ & $\mathbf{2 0 0 9}$ & $\mathbf{2 0 0 9}$ & $\mathbf{2 0 0 9}$ & $\mathbf{2 0 0 9}$ \\
& $\mathbf{Q 1}$ & $\mathbf{0 2}$ & $\mathbf{0 3}$ & $\mathbf{0 4}$ & $\mathbf{0 1}$ & $\mathbf{0 2}$ & $\mathbf{0 3}$ & $\mathbf{0 4 1}$ \\
\hline Exports & & & & & & & & \\
East Asia & 23.7 & 25.1 & 28.2 & 4.5 & -23.4 & -24.2 & -18.0 & 8.2 \\
Japan & 12.1 & 18.0 & 18.1 & 7.9 & -16.7 & -23.8 & -16.3 & -6.7 \\
Developing & 31.2 & 29.2 & 33.9 & 2.7 & -24.1 & -24.5 & -28.7 & 7.5 \\
East Asia & & & & & & & & \\
Korea & 33.1 & 38.3 & 52.9 & 7.5 & -29.2 & -36.6 & -35.0 & -3.0 \\
Taiwan & 15.4 & 21.1 & 17.3 & -10.4 & -34.5 & -38.8 & -21.4 & 20.1 \\
Hong Kong, & 10.8 & 6.5 & 11.0 & -9.9 & -24.0 & -21.6 & -16.6 & 12.2 \\
China & & & & & & & & \\
ASEAN & 34.2 & 26.0 & 27.4 & 2.8 & -22.6 & -16.8 & -9.6 & 23.0 \\
Indonesia & 33.2 & 41.5 & 54.8 & 20.2 & -26.4 & -21.0 & -24.0 & 21.3 \\
Malaysia & 33.3 & 28.2 & 20.8 & 7.1 & -23.9 & -12.2 & -9.1 & 9.2 \\
Philippines & 30.4 & 22.8 & 34.5 & 1.3 & -11.8 & -18.7 & -8.5 & 18.6 \\
Singapore & 15.3 & 5.9 & 17.1 & -0.6 & -17.1 & -12.3 & -16.2 & 21.4
\end{tabular}

9 This inference is based on monthly export data extracted from the CEIC Data Company (not reported here for want of space). 
China: The Next Twenty Years of Reform and Development

\begin{tabular}{|c|c|c|c|c|c|c|c|c|}
\hline Thailand & 37.2 & 42.1 & 38.3 & 5.9 & -27.3 & -29.6 & -14.3 & 21.1 \\
\hline Vietnam & 88.8 & 45.1 & 16.0 & -11.1 & -30.0 & -15.9 & 36.3 & 58.9 \\
\hline $\begin{array}{l}\text { United } \\
\text { States }\end{array}$ & 5.4 & 12.2 & 15.3 & 0.7 & -15.4 & -18.5 & -16.7 & 1.4 \\
\hline $\begin{array}{l}\text { European } \\
\text { Union }\end{array}$ & 25.0 & 29.7 & 23.5 & 4.1 & -22.6 & -26.6 & -23.6 & -4.2 \\
\hline $\begin{array}{l}\text { Total } \\
\text { exports }\end{array}$ & 16.3 & 19.0 & 20.2 & 0.9 & -21.1 & -23.5 & -20.3 & 7.2 \\
\hline \multicolumn{9}{|l|}{ Imports } \\
\hline East Asia & 18.8 & 24.1 & 13.2 & -18.1 & -33.7 & -23.1 & -12.5 & 30.2 \\
\hline Japan & 17.0 & 23.7 & 18.7 & -5.0 & -29.8 & -21.4 & -13.4 & 15.6 \\
\hline $\begin{array}{l}\text { Developing } \\
\text { East Asia }\end{array}$ & 19.6 & 24.3 & 10.8 & -23.6 & -35.3 & -23.8 & -12.1 & 37.7 \\
\hline Korea & 14.9 & 25.0 & 14.8 & -18.5 & -26.6 & -18.8 & -10.2 & 33.6 \\
\hline Taiwan & 24.5 & 24.2 & 5.0 & -33.3 & -43.9 & -29.9 & -14.9 & 43.8 \\
\hline Hong Kong & 26.0 & -2.5 & 11.0 & -21.4 & -49.1 & -32.9 & -33.3 & -7.7 \\
\hline ASEAN & 19.9 & 23.8 & 12.7 & -18.9 & -33.8 & -22.1 & -8.9 & 12.2 \\
\hline Indonesia & 31.7 & 30.3 & 17.3 & -13.5 & -38.0 & -18.4 & -6.3 & 69.6 \\
\hline Malaysia & 18.4 & 29.5 & 22.4 & -16.1 & -25.0 & -17.0 & -3.5 & 60.3 \\
\hline $\begin{array}{l}\text { The } \\
\text { Philippines }\end{array}$ & 12.7 & 5.7 & -23.2 & -48.6 & -61.3 & -51.7 & -30.3 & 17.6 \\
\hline Singapore & 6.7 & 35.5 & 27.4 & -9.3 & -23.7 & -28.2 & -11.9 & 27.2 \\
\hline Thailand & 26.0 & 22.9 & 15.8 & -5.6 & -29.2 & -6.6 & -0.9 & 29.7 \\
\hline Vietnam & 64.3 & 19.0 & 69.4 & 6.8 & -7.9 & 23.6 & -8.3 & 47.7 \\
\hline $\begin{array}{l}\text { United } \\
\text { States }\end{array}$ & 29.7 & 23.0 & 15.7 & 3.7 & -17.7 & -13.1 & -6.4 & 19.3 \\
\hline $\begin{array}{l}\text { European } \\
\text { Union }\end{array}$ & 25.9 & 33.0 & 22.7 & 2.3 & -14.7 & -11.2 & -2.2 & 14.9 \\
\hline $\begin{array}{l}\text { Total } \\
\text { imports }\end{array}$ & 21.2 & 25.0 & 15.1 & -12.2 & -28.3 & -19.6 & -11.9 & 10.2 \\
\hline
\end{tabular}

1 Average for October and November

Note: Growth rates calculated using current US dollar values.

Source: Compiled from CEIC Data Company.

Data on export growth by major commodity categories for Chinese imports and exports are summarised in Table 10.9. A notable pattern is the relatively sharper contraction in the category of machinery exports (in which network trade is heavily concentrated) compared with other product categories - in particular, traditional labour-intensive products (textiles and garments, footwear and other miscellaneous manufactures). Exports belonging to this commodity categoryin particular, ICT products and consumer electronics - are also predominantly consumer durables, which, as already noted, are generally more susceptible to income contraction. In traditional labour-intensive products, developingcountry producers have the ability to perform better purely on the basis of cost competitiveness even in the context of depressed demand. 
Table 10.9 China: growth of merchandise exports and imports by commodity category, 200801 - 200903 (year-on-year percentage change, current US\$)

\begin{tabular}{|c|c|c|c|c|c|c|c|}
\hline & $\begin{array}{c}2008 \\
01\end{array}$ & $\begin{array}{c}2008 \\
02\end{array}$ & $\begin{array}{c}2008 \\
03\end{array}$ & $\begin{array}{c}2008 \\
04\end{array}$ & $\begin{array}{c}2009 \\
01\end{array}$ & $\begin{array}{c}2009 \\
02\end{array}$ & $\begin{array}{c}2009 \\
03\end{array}$ \\
\hline \multicolumn{8}{|l|}{ Exports } \\
\hline Total exports & 16.3 & 19.0 & 20.2 & 0.9 & -21.1 & -23.5 & -20.3 \\
\hline Primary & 16.3 & 24.9 & 29.9 & 8.6 & -17.9 & -13.6 & -14.2 \\
\hline Manufacturing & 21.2 & 23.8 & 22.0 & 2.6 & -20.7 & -18.2 & -17.2 \\
\hline $\begin{array}{l}\text { Products of chemical or } \\
\text { allied industries }\end{array}$ & 48.5 & 54.0 & 42.2 & 3.1 & -25.2 & -24.9 & -23.4 \\
\hline $\begin{array}{l}\text { Plastics and articles } \\
\text { thereof, rubber and rubber } \\
\text { articles }\end{array}$ & 13.8 & 10.1 & 16.1 & 10.7 & -21.1 & -17.1 & -17.3 \\
\hline Textiles and textile articles & 22.5 & 5.3 & 4.1 & 8.0 & -11.4 & 2.6 & 4.2 \\
\hline $\begin{array}{l}\text { Footwear, headgear, } \\
\text { umbrellas, etc. }\end{array}$ & 14.7 & 14.4 & 19.7 & 21.3 & -1.3 & 7.2 & 8.2 \\
\hline $\begin{array}{l}\text { Base metals and articles } \\
\text { of base metal }\end{array}$ & 23.3 & 18.5 & 26.4 & 22.0 & -9.0 & -1.5 & -4.3 \\
\hline $\begin{array}{l}\text { Machinery and mechanical } \\
\text { appliances, etc. }\end{array}$ & 15.9 & -15.7 & 20.9 & 4.3 & -31.6 & -38.8 & -42.1 \\
\hline Electronics & 6.2 & 12.5 & 61.5 & 17.2 & -33.5 & -36.5 & -37.3 \\
\hline $\begin{array}{l}\text { Electrical machinery and } \\
\text { equipment }\end{array}$ & 20.3 & 27.0 & 20.4 & -1.1 & -21.5 & -19.5 & -20.2 \\
\hline $\begin{array}{l}\text { Miscellaneous manufactured } \\
\text { articles }\end{array}$ & 41.5 & 39.0 & 31.7 & 9.1 & -17.0 & -19.7 & -6.2 \\
\hline Imports & $\begin{array}{c}2008 \\
01\end{array}$ & $\begin{array}{c}2008 \\
02\end{array}$ & $\begin{array}{c}2008 \\
03\end{array}$ & $\begin{array}{c}2008 \\
04\end{array}$ & $\begin{array}{c}2009 \\
01\end{array}$ & $\begin{array}{l}2009 \\
02\end{array}$ & $\begin{array}{c}2009 \\
03\end{array}$ \\
\hline Total imports & 21.2 & 25.0 & 15.1 & -12.2 & -28.3 & -19.6 & -11.9 \\
\hline Primary & 73.5 & 74.9 & 72.5 & 5.2 & -40.7 & -35.3 & -27.2 \\
\hline Manufacturing & 16.3 & 19.1 & 11.4 & -12.1 & -26.2 & -21.1 & -19.2 \\
\hline $\begin{array}{l}\text { Products of chemical or allied } \\
\text { industries }\end{array}$ & 19.6 & 23.5 & 19.6 & -10.5 & -23.9 & -18.2 & -16.3 \\
\hline $\begin{array}{l}\text { Plastics and articles thereof, } \\
\text { rubber and rubber articles }\end{array}$ & 16.3 & 22.5 & 22.7 & -15.6 & -29.2 & -20.1 & 15.2 \\
\hline Textiles and textile articles & 6.3 & 2.7 & -3.4 & -9.2 & -22.8 & -22.8 & -23.2 \\
\hline $\begin{array}{l}\text { Footwear, headgear, } \\
\text { umbrellas, etc. }\end{array}$ & 47.5 & 47.7 & 24.8 & 12.6 & -2.8 & -18.7 & -22.2 \\
\hline $\begin{array}{l}\text { Base metals and articles of } \\
\text { base metal }\end{array}$ & 14.1 & 5.8 & 8.3 & -15.0 & -26.3 & -16.9 & -2.7 \\
\hline $\begin{array}{l}\text { Machinery and mechanical } \\
\text { appliances, etc. }\end{array}$ & 11.7 & 18.0 & 9.8 & -10.7 & -24.1 & -17.9 & -8.2 \\
\hline Electronics & 16.3 & 19.9 & 15.0 & -1.0 & -19.8 & -19.5 & -3.2 \\
\hline $\begin{array}{l}\text { Electrical machinery and } \\
\text { equipment }\end{array}$ & 9.5 & 17.1 & 7.4 & -15.2 & -26.3 & -17.4 & -6.7 \\
\hline $\begin{array}{l}\text { Miscellaneous manufactured } \\
\text { articles }\end{array}$ & 11.6 & 20.8 & 1.4 & -8.1 & -5.4 & 1.6 & 2.2 \\
\hline
\end{tabular}




\section{Policy options}

At the time of writing this chapter (mid June 2010), 'the global recovery is proceeding better than expected' (IMF 2010:1). Industrial production in the United States and other major industrialised countries has begun to recover and the downward spiral in world trade volume has abated. The economic forces unleashed by the crisis will, however, probably run rampant for years. The recovery has so far been driven largely by unprecedented fiscal and monetary stimulus and there is considerable downside risk to sustainability stemming from fiscal fragility. In the medium term, the United States and other crisisaffected industrialised countries will have to save more and spend less in order to wind down the massive accumulated household and public debt. Given this global economic outlook, what are the policy options available to governments in China and other East Asian countries that have hitherto depended largely on export-driven growth?

There has been a growing emphasis in Asian policy circles on the need for rebalancing growth: engineering a structural shift in aggregate demand away from exports and towards domestic markets (ADB 2010). The policy measures under consideration include measures to redress the export bias in the incentive structure, to reduce high saving propensities with a view to boosting domestic consumer demand and to promote domestic non-tradable (services) production. The major focus of this policy advocacy is on China.

China's degree of export dependence is unusually high for a continental economy of China's size. China's export to gross domestic product (GDP) ratio (about 40 per cent) grossly exaggerates its export dependence because of the heavy import dependence of assembly exports, which account for more than two-thirds of total merchandise exports. Even the available adjusted estimates (about 20 per cent), however, seem too high for China's potential economic size. Moreover, the unusually high domestic saving rates, the vast population base, highly repressed domestic financial system and excessively high urban-rural household income gap all indicate the vast potential for policy-induced domestic demand-led growth in China. Growth rebalancing will not only enable China to deal effectively with massive external imbalances while cushioning growth momentum against external demand shocks, it will engineer a critical shift in the focus of national development policy from the quantity to the quality of growth, with a view to redressing urban-rural disparities and achieving social harmony.

The need to embark on a major structural transition from export-led to domestic demand-led growth was recognised by the Chinese leadership well before the onset of the global financial crisis (Roach 2009:229-33). The eleventh Five- 
Year Plan enacted in March 2006 stressed the imperatives of an enhanced, broad-based social safety net (encompassing not just social security but rural health care and education) to improve income security, thereby reducing the excess precautionary savings that continue to inhibit the expansion of private consumption. Chinese authorities have, however, so far failed to put this policy into action, presumably because of strong domestic political pressure to maintain the momentum of employment-intensive growth through export orientation (Yu 2007; Fan 2008).

Success on the rebalancing front will naturally involve an appreciation of China's real exchange rate $\mathrm{i}^{10}$ - that is, a reduction in the profitability of tradable production relative to non-tradable production. But this is unlikely to impedeat least in the medium term - China's role as the premier assembly centre within regional production networks. Even after three decades of rapid growth, the average hourly wage rate for Chinese manufacturing of US\$3.20 is still (as in 2007) only 13 per cent of the US hourly wage rate of US\$24.40. ${ }^{11}$ About half of China's massive labour force (about 745 million people) is still engaged in agriculture, where productivity is, on average, barely one-eighth of that in industry and about one-quarter of that in the service sector. This, coupled with the high skilled-unskilled wage differential — which, according to Blanchard and Giavazzi (2006), has risen from 1.3 to 2.1 in the past decade - suggests that China still has much potential for moving unskilled workers out of agriculture and into manufacturing and other productive urban-sector activities. ${ }^{12}$

The pressure for maintaining export competition in a context of slow-growing world demand could provide a fertile setting for the rise of trade frictions and protectionism (Bhagwati 1988; Erixson and Razeen 2009). Fortunately, there has not yet been a protectionist backlash in the form of erecting tariff walls, as happened during the Great Depression. There are, however, already signs that countries are resorting to protection 'disguises' in the form of filing antidumping complaints and imposing stringent implementation of technical, sanitary and phyto-sanitary standards, in addition to the massive financial support extended by the United States and some other countries to automobile manufacturers (Gamberoni and Newfarmer 2009). The number of legislative measures introduced in the US Congress that involve some form of sanction on China's trade has multiplied in recent years (Roach 2009:241). There is

10 Whether it would be preferable to achieve this by adjustments to the nominal exchange rate rather than by adjustment of domestic prices remains a subject of controversy, which is beyond the scope of this chapter. See the chapters by Xiao Geng, and Rod Tyers and Ying Zhang in this volume.

11 Data from the US Bureau of Labor Statistics web site (<ftp.bls.gov $>$ ).

12 In recent years, there have been many scattered cases of rising wages and worker shortages in industrial cities in China. One cannot, however, realistically infer this evidence as indicative of a broader macroeconomic trend of emerging labour shortages given that the Chinese economy is still a long way from having a fully functioning labour market. These cases could well reflect skill mismatches and frictional dislocations in a highly imperfect labour market rather than genuine labour shortages. 
therefore a strong case for devising strategies to fight new protectionism as part of a long-term commitment to non-discriminatory multilateral and unilateral liberalisation. The Information Technology Agreement, which came into force in 1997, seems to be a promising example to follow (Elek 2008). There is also a case for Asia's Group of 20 (G20) countries and the ASEAN Secretariat to consolidate their positions against protectionist tendencies. As part of its efforts to keep export markets open, China should resist the temptation to use export subsidies and other selective policies to support its export sector. In an era of rising unemployment and the resultant backlash against globalisation in the United States and other industrialised countries, giving in to such temptation could be a recipe for anti-China trade sanctions.

One option under consideration in Asian policy circles for supporting regional trade growth in the face of slow growth in world demand is to form a regionwide free-trade agreement (FTA), encompassing ASEAN, China, Japan and Korea (and possibly India) (Kawai and Wignaraja 2009; ADB 2009). The logic behind this proposal in relation to the network trade in the region is that trade within global production networks (both in components and final assembly) is generally more sensitive to tariff changes than is final trade (or total trade as captured in published trade data) (Yi 2003). Normally a tariff is incurred each time a good-in-process crosses a border. Consequently, a 1 percentage point reduction in tariffs leads to a decline in the cost of production of a vertically integrated good by a multiple of this initial reduction - in contrast with a 1 per cent decline in the cost of a regular traded good. Tariff reductions can also make it more profitable for goods that were previously produced entirely in one country to become vertically specialised. Consequently, in theory, the tradestimulating effect of FTAs would be higher for network trade than for normal trade, other things remaining unchanged.

In our view, however, this is a risky strategy, given Asia's heavy reliance on extra-regional markets for its export dynamism. Such a move would invite swift retaliation by the United States and the European Union, and possibly others. A firm commitment as part of the FTA to not increase existing tariff and non-tariff barriers against non-members is unlikely to avert this threat because an Asiawide FTA - given that it would encompass a number of significant world trading nations - is likely to involve significant trade diversion even under the existing extra-regional tariffs. In any case, the chances of negotiating a region-wide FTA look rather slim in the context of the continuing crisis. In particular, China might not want to get involved in such an endeavour, not only because of its new emphasis on domestic-oriented growth but because of its official commitment to averting protectionist backlashes in industrialised countries. ${ }^{13}$ Governments

13 See, for instance, the recent article written by the Chinese Minister of Trade for the Wall Street Journal (Deming 2009). 
in South-East Asian countries are also concerned that any region-wide attempt to liberalise trade would give China an unfair advantage in attracting foreign direct investment (FDI) involved in global production networks, given its vast domestic economy characterised by regional differences in costs of production. ${ }^{14}$

In reality, the trade effects of any FTA would depend very much on the nature of the rules-of-origin (ROO) built into it. In particular, there are three main complications involved in bringing network trade under FTAs (or other preferential trading arrangements). First, formulating ROOs for network-related trade is a rather complicated business. The conventional value-added criterion is not virtually applicable to this trade because the products involved are low value added by their very nature. The only viable option is to go for ROOs based on 'change in tariff lines', but this leads to insurmountable administrative problems because trade in electrical and electronic goods and the related components belongs to the same tariff code at the HS- 6 digit level, which is the normal basis for designing this type of ROO (Kohpaiboon 2008:App. 2). For example, electrical appliance assembly plants in Thailand that use imported bare-printed circuit boards (BPCB) together with other locally procured electronic components (for example, diodes, integrated circuits, semi-conductors) for printed circuit-board assembly (PCBA) for export are not eligible for FTA concessions because BPCBs and PCBAs belong to the same HS code (853690).

Second, the process of network-based global production sharing is characterised by the continuous emergence of new products. Given the obvious administrative problems involved in revising ROOs in tandem, these product inventions and innovations naturally open up room for unnecessary administrative delays and/or the tweaking of rules as a means of disguised protection (Elek 2008). Moreover, given the importance of extra-regional markets for final goods for the growth dynamism of production networks in Asia, maintaining barriers to trade against non-members (while allowing free trade among members) can thwart the 'natural' expansion of global production sharing. Third, twisting ROOs for the purpose of import-competing industries becomes easier when the production process involves procuring components from a number of sources; tightening ROOs on the procurement of one critical input would suffice to protect competing domestic producers of the final (assembled) product. ${ }^{15}$

\footnotetext{
14 This point is based on interviews with high-ranking officials in the Thai Ministry of Foreign Affairs.

15 ROOs relating to television sets (HS852812) in the Thailand-Australia Free Trade Agreement (Annex 4.1) can be used to illustrate this point. To become eligible for preferential tariffs, television producers must source three parts (HS701120, 854011 and 854091) locally. Television picture tubes (HS854011) are not, however, produced in Thailand and Thai colour-television assembly is viable only if this item is procured from Japan, Taiwan or Korea. Thus, even though a preferential tariff on televisions under the FTA (20 per cent) is very attractive, the Thailand-Australia FTA is virtually irrelevant for television assembly plants located in Thailand.
} 
Finally, it is important to note that the available evidence on the operation of FTAs in operation in the region (and beyond) does not augur well for the potency of a new region-wide FTA. Presumably because of the operational complications noted above, the real utilisation rates of tariff concessions provided under these FTAs are rather low - ranging from about 5 per cent to 20 per cent across different product categories (Takahashi and Urata 2008; Kawai and Wignaraja 2009; Kohpaiboon 2008). Moreover, there is evidence that utilisation rates are often firm or industry specific and are higher in large firms, firms with close trade and FDI ties and firms located in particular industries in which meeting ROO requirements is simple and straightforward. The upshot is that FTAs are unlikely to have the potential to promote trade in a neutral and broad-based fashion.

\section{Conclusions}

Intra-regional trade shares based on conventional trade data are generally consistent with the view that East Asia has become increasingly integrated through merchandise trade. When the continuing process of global production sharing and East Asia's unique role in China-centred global production networks are appropriately taken into account, it is clearly evident, however, that the increase over time in intra-regional trade ratios has emanated largely from the rapid increase in intra-regional imports, while intra-regional export expansion has persistently lagged behind. The asymmetry in intra-regional shares between imports and exports is much sharper when reported trade data are adjusted for trade in parts and components. Clearly, the region's dependence on the rest of the world for its trade expansion has in fact increased over time.

This inference is basically consistent with the behaviour of trade flows since the onset of the global financial crisis. The remarkably synchronised nature of the trade contraction across countries in the region is generally consistent with the close trade ties within East Asia-forged within regional production networks. While many had hoped that China would provide a cushion for this export contraction - as would have been consistent with the decoupling thesis - this did not turn out to be the case.

The rise of global production sharing has strengthened the case for a global, rather than a regional, approach to trade policymaking. Given the global orientation of the region's economies, we question whether there would be any significant positive pay-off from forming a region-wide FTA. In any case, it is doubtful whether an FTA approach to trade liberalisation is feasible in a context in which global production networks are rapidly expanding, seamlessly encompassing many industries and countries. 
The recent and prospective developments in the global economy since the global financial crisis make a strong case for China to go ahead with the speedy implementation of the growth-rebalancing policy embodied in its eleventh Five-Year Plan. Given the nature of domestic factor-market conditions and the continuing changes in the process of global production sharing, promoting domestic demand-oriented growth and engagement in global production sharing is not a mutually exclusive policy priority for China in the medium term. Successful growth rebalancing has the potential to facilitate the further expansion of network trade by averting trade friction and retaliation. An enlarged domestic market would also have the potential to improve the international competitiveness of exporting firms within production networks by reducing unit costs of production. Looking further ahead, increases in domestic income and wages under a successfully balanced growth strategy would provide the setting for China to move up the value ladder within global production networks. After all, the bulk (more than 60 per cent) of international exchange within global production networks takes place among industrialised countries and, in the future, China will surely become one of these.

\section{References}

Asian Development Bank (ADB) 2009, Asian Development Outlook 2009: Rebalancing Asia's growth, Asian Development Bank, Manila.

Asian Development Bank (ADB) 2010, Asian Development Outlook 2010: Macroeconomic management Beyond he Crisis, Asian Development Bank, Manila.

Almunia, M., Benetrix, A., Eichengreen, B., O'Rourke, K. H. and Rua, G. 2010, 'From Great Depression to great credit crisis: similarities, differences and lessons', Economic Policy, April, pp. 219-65.

Athukorala, P.-c. 2005, 'Product fragmentation and trade patterns in East Asia', Asian Economic Papers, vol. 4, no. 3, pp. 1-27.

Athukorala, P.-c. 2009a, 'The rise of China and East Asian export performance: is the crowding-out fear warranted?', World Economy, vol. 32, no. 2, pp. 234-66.

Athukorala, P.-c. 2009b, 'China and Southeast Asia in the new division of labour', in L. Yueh (ed.), The Future of Asian Trade and Growth: Economic development with the emergence of China, Routledge, London, pp. 406-31. 
Athukorala, P.-c. 2009c, Production networks and trade patterns: East Asia in a global context, Trade and Development Discussion Paper 2009/08, Division of Economics, Research School of Pacific and Asian Studies, The Australian National University, Canberra.

Bergsten, C. F., Gill, B., Lardy, N. R. and Mitchell, D. 2006, China: The balance sheet, Public Affairs, New York.

Blanchard, O. and Giavazzi, F. 2006, 'Rebalancing growth in China: a threehanded approach', China and World Economy, vol. 14, no. 4, pp. 1-20.

Bhagwati, J. 1988, Protectionism, MIT Press, Cambridge, Mass.

CEIC Data Company, New York. Data downloaded from www.ceicdata.com

Council for Economic Planning and Development n.d., Trade Data, CD-ROM, Council for Economic Planning and Development, Taipei.

Deming, C. 2009, 'China calls on the world's governments to learn from history', Wall Street Journal, 20 February.

Elek, A. 2008, Immunizing future protectionists: preventing the emergence of more sensitive sectors, Asia Pacific Economic Papers 372, Australia-Japan Research Centre, The Australian National University, Canberra.

Erixson, F. and Razeen, S. 2009, 'Fighting the urge for protectionism', Far Eastern Economic Review, vol. 172, no. 1 (January/February), pp. 28-31.

Fan, G. 2008, 'Renminbi revaluation and US dollar depreciation', in M. Goldstein and N. R. Lardy (eds), Debating China's Exchange Rate Policy, Peterson Institute for International Economics, Washington, DC.

Fukao, K. and Yuan, T. 2009, 'Why is Japan so heavily affected by the global economic crisis?', voxeu.org, 8 June.

Gamberoni, E. and Newfarmer, R. 2009, 'Trade protection: incipient but worrisome trends', voxeu.org, 4 March 2009.

Garnaut, R. 2003, Australia and Japan: time to be important to each other again, Address to the Australia-Japan Business Committee Conference, Kyoto, 5 October 2003.

International Monetary Fund (IMF) 2010, Global Economic Outlook: Rebalancing growth, International Monetary Fund, Washington, DC.

Kawai, M. and Wignaraja, G. 2008, The Asian noodle bowl: is it serious for business?, ADBI Working Paper 136, Asian Development Bank Institute, Tokyo. 
Kawai, M. and Wignaraja, G. 2009, 'Multilateralising Regional Trading Agreements in Asia', in Multilateralizing Regionalism: Challenges for the Global Trading System, edited by Richard Baldwin and Patrick Low. Cambridge UK: Cambridge University Press.

Krugman, P. 2009, The return of depression economics, Lionel Robbins Lecture, London School of Economics, <http/cep.lse.ac.uk/_new/events/special_ post.asp $>$

Kohpaiboon, A. 2008, Exporters' response to AFTA tariff preferences: evidence from Thailand, Paper presented at the East Asian Economic Congress, Manila.

Park, Y. C. and Shin, K. 2009, 'Economic integration and changes in the business cycle in East Asia: is the region decoupling from the rest of the world?', Asian Economic Papers, vol. 8, no. 1, pp. 107-40.

Roach, S. 2009, The Next Asia: Opportunities and challenges for a new globalization, John Wiley, Hoboken, NJ.

Takahashi, K. and Urata, S. 2008, On the use of FTAs by Japanese firms, RIETI Discussion Paper 08-E-002, Graduate School of Asia-Pacific Studies, Waseda University, Japan.

United Nations (UN) n.d., Comtrade database, United Nations, New York.

Urata, S. 2006, A shift from market-driven to institution-driven regionalization in East Asia, Paper presented to Conference on Economic Policy Reform in Asia, Stanford University, California., June.

Yoshitomi, M. 2007, 'Global imbalances and East Asian monetary cooperation', in D.-K. Chung and B. Eichengreen (eds), Towards An East Asian Exchange Rate Regime, Brookings Institution Press, Washington, DC, pp. 22-48.

Yi, K. 2003, 'Can vertical specialization explain the growth of world trade', Journal of Political Economy, 111 (1), 52-102.

Yu, Y. 2007, 'Global imbalances and China', The Australian Economic Review, vol. 40, pp. 3-23. Geng Xiao. 